\title{
Rainwater Harvesting for Recharging Groundwater and Local Water Management in Kathmandu Valley
}

D espite having about $1500 \mathrm{~mm}$ of annual rainfall (equivalent to 15 million litres per hectare) in Kathmandu Valley, there is acute drinking water shortage. Against a demand of 350 MLD, the supply is only 135 million litres per day (MLD) in the wet season and 90 MLD in the dry season (personal communication with Suresh P. Acharya, Spokesperson for KUKL). The ground water contribution in Kathmandu Upatyaka Khanepani Limited (KUKL) supply is $35 \%$ in the wet season and $65 \%$ in the dry season (Suresh P. Acharya, Spokesperson for KUKL). This is the withdrawal by KUKL. In addition, almost all the hotels, large industries and households also extensively use groundwater by deep/shallow well pumping. The deep aquifer of the Kathmandu Valley gets very little recharge and it is actually a water mine which was created about 2,00,000 to 4,00,000 years ago. The pumping from the deep aquifer is 20 times more than the recharge to it (Creswell et al 2001). The annual drawdown of the deep aquifer water table is lowering by $2.5 \mathrm{~m}$ every year as invariably quoted by many sources. The haphazard pumping may deteriorate the situation in the coming years resulting in land subsidence. The Kathmandu Valley Water Supply Management Board (KVWSMB) has only recently started some action for enforcing license for groundwater use six years after its establishment. Increased vigilance by the Board is required to control the haphazard pumping in the valley. The Board has not started advocacy and information dissemination drive to an acceptable level on rain water harvesting apart from the distribution of some pamphlets in this regard.

The Kathmandu Valley's population is 2.51 million (census 2011). In addition, there is $30 \%$ floating population. Due to the availability of various opportunities, the population of the Valley is expected to be rapidly increased in future to say 5.76 million by the year 2025 (KVWSWSI 2010). At present, the water requirement is $41 \mathrm{lpcd}$ and expected to grow to 135 lpcd in 2025.

The much publicized Melamchi Water Supply Project was scheduled to be completed in 2011; however, the project is not expected to be commissioned before 2016. 170 MLD is expected to be diverted in the 1st phase, an additional 170 MLD from Yangri, and another additional 170 MLD from Larke Rivers are proposed to be diverted in subsequent phases. In the interim period, till the completion of the Melamchi project, alternate water supply needs to be explored in a sustainable way. Due to rising population and standard of living, even such additional diverted flows will not be sufficient to cater for the burgeoning population of the Valley.

Due to rapid urbanization, the large land surfaces are sealed by concrete and road pavements so that water does not percolate to the groundwater aquifer. Hence, artificial recharge to the groundwater is one of the best solutions for which increased information dissemination/advocacy to the public is necessary. For this to materialize, agency level, industry/business level and household level recharging are necessary. However, all the related parties are not serious in this respect. The Kathmandu Municipality has announced a 10\% rebate in its Building plan approval fee collection for house construction by proposing the installation of rainwater

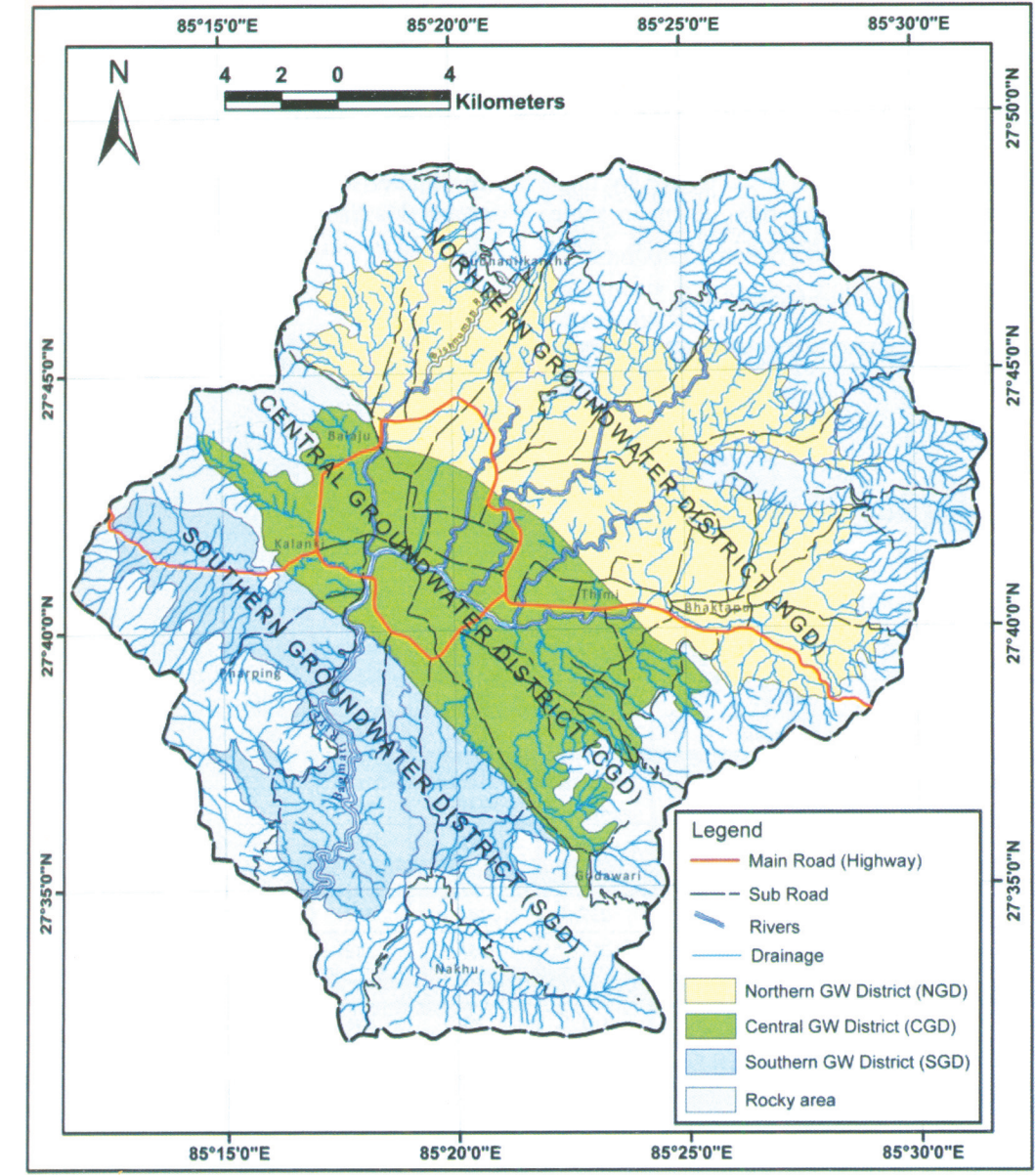

Figure 1. Hydrological Districts in the Kathmandu Valley (Shrestha, Pradhanang and Pandey 2012). 
harvesting and/or groundwater recharge system. But due to inadequate publicity drive, no progress has been made so far.

Recently, some private companies have been established to provide services of rain water harvesting system construction. Further, Centre for Integrated Urban Development (CIUD) with support from Donors has undertaken Kathmandu Recharge Project and constructed some rain water harvesting/recharge systems in about 8 places focusing mostly in schools of the Kathmandu Valley.

\section{Local Water Management}

We now discuss some of the possible ways to economize on water use and harvesting of rainwater.

\section{Rainwater Harvesting}

Most of the large water consuming industries and businesses directly pump from groundwater and no measures are taken for the recharge. For example, CocaCola, Pepsi Cola, bottling plants, motor cycle workshops/ servicing, car washing etc. consume considerable water. Collecting and storing rainwater will not require large storages due to daily use. Spill from these storages need to be used for recharges. Some agencies like KVWSMB need to spread this information to the related agencies through pamphlets, letters, advertisements and also by introducing suitable legislation. The said industries usually have large roof areas suitable for rainwater harvesting. Further, the cost of such water collection/ storage system is nominal for such industries/business. It is only a case of willingness for implementation, or not knowing the possibility of such harvesting.

Increased advocacy and information dissemination is required to convince the people on the benefits of rain water harvesting.

\section{Recharge of groundwater}

The Kathmandu Valley has three district regions, a) the north region with porous media, b) the central region, and c) the southern region (Figure 1). The central and southern regions due to thick layers of clay are not suitable for recharging. The north region (especially the north-east of Kathmandu) is the place suitable for large scale artificial recharge.

In 2000, a pilot recharge project was undertaken to test the recharge to the deep groundwater aquifer. Only filtered water through a pressure filter was sent (by 2 inches diameter pipe) through a deep tube well for artificial recharge. Recharge went on well for 2 weeks; however after that, the recharge rate was considerably lowered (personal communication with Mr. Pravakar Man Singh). The results were not very encouraging for the cost involved. The recharge rate was small. One conclusion was that, it is easier to recharge a shallow aquifer rather than the deep one. A study undertaken by Vishnu Pandey et al, 2012 has indicated that the potential for recharge of the shallow aquifer is about nine times more than the deep aquifer.

In Kathmandu Valley, large surfaces such as road areas, particularly roads in slope where it is easy to collect rainwater may be utilized for collection of rain water in a small pond and recharge to the groundwater after filtration in a gravel/sand bed. Related agencies such as the roads department and town development committee are unaware of such possibility. If water harvesting system is introduced during road construction, it would be easy achievable with a lower cost. For example, the Tinkune area of Kathmandu with very wide roads offered a very good potential site during road construction. Presently, road widening in many areas of Kathmandu is ongoing with installation of drainage system. This is an opportunity to introduce rainwater rechargeto the ground water aquifer wherever feasible. Hence, KVWSMB need to coordinate with the Roads Department, Kathmandu Town Development Authority.

The north-eastern area of Kathmandu is suitable for such recharge. At present, there is no water shortage in the north-eastern region (Recharge zone) of Kathmandu; and hence, locals are not interested in ground water recharge. However, the population of this areas are fast growing and it is time to plan now (personal communication with Dr. Suresh Das Shrestha). One of the problems is that land price in the Kathmandu Valley is very high for making very large ponds and reservoirs. Hence, innovative planning will be required such as combining fish farming with that of the recharge ponds.

In the monsoon period, where there is sufficient rainfall, the shallow water table is usually high near the ground, where the recharge cannot be done substantially. In the dry season, when the water table is lowered, there is no rainfall for recharge. Hence, innovative techniques are required. Water needs to be stored in ponds and reservoirs and slowly allowed to recharge to compensate for the depletion of ground water. Additional investigation will be required to pinpoint the recharge areas along with drilling/logging and mapping of such areas.

\section{Water Saving Techniques}

Other potential area will be the local household level water management. Installation of simple rainwater harvesting system coupled with groundwater recharge will be helpful. The modern toilet consumes a substantial portion of the water supply for flushing. For toilet flushing, the used water from a bath or clothes washing can be reutilized inducing reduced water consumption. The used water of the showers/baths needs to be collected and used for flushing household toilets.

Dr. Roshan Raj Shrestha, a UN-HABITAT official and also a practitioner of local water management, has installed a dry toilet in his home in Kathmandu, which does not require any water for flushing. In Israel, the sewage water stored in a pond is directly used for the irrigation of fruit trees through sprinklers without any treatment.

There a is need for widespread advocacy, 
dissemination of information to the households, industry and at agency level for water saving practices and reusing wastewater wherever feasible. Several NGOs in Kathmandu with donor support spend resources in workshops and conferences in star hotels; whereas they do not give sufficient attention to dissemination/ advocacy of very simple technology of rainwater harvesting/local water management.

\section{Conclusion}

It is an irony to allow about $1500 \mathrm{~mm}$ of annual rainfall a year (equivalent to 15 million litres per Hectare) to drain away, and make a hue and cry for water in the dry season. There is a great possibility to recharge the ground water aquifer by artificial recharging, especially the shallow aquifer. It is also most necessary to counter the rapid lowering of the water table (deep aquifer) by $2.5 \mathrm{~m}$ every year due to unsustainable over pumping with the probability of land subsidence. The people of Kathmandu must be made aware of the imminent danger. The related agencies such as KVWSMB must plan and disseminate the required information to entice the practice of rain water harvesting, artificial recharge along with water saving practices.
Jeewan P. Thanju, B.Sc. (Civil), M. Engr., has a background in water resources and is currently the Editor-in-Chief of HYDRO Nepal journal.

Corresponding address:jpthanju@yahoo.com

\section{References}

Creswell, R. G., J. Bauld, G. Jacobson, M.S. Khadka, M.G. Jha, M.P. Shrestha and S. Regmi, 2001, A first estimate of groundwater ages for the deep aquifer of the Kathmandu Basin, Nepal, using the radioisotope chlorine-36. Ground Water, 39, 449-457.

KVWSWSI, 2010, Kathmandu Valley Water Supply and Waste Water System Improvement (KVWSWSI) Project Feasibility Study, PPTA 4893-NEP Final Report, ADB and KUKL, Nepal.

Shrestha, Sangam, Pradhananga, D., Pandey, V.P. (Ed.), 2011, Kathmandu Valley Groundwater Outlook, Published by AIT, The Small Earth Nepal, Centre for Research for Environment Energy and water (CREEW), Kathmandu, International Research Centre for River Basin Environment-University of Yamanashi (ICRE-UK), Kofu, Yamanashi, Japan.

\section{CALENDAR OF EVENTS - ENERGY}

30-31 August, 2012: Western Energy Policy Research Conference. Location: Boise, Idaho, USA. More info: http://epi.boisestate.edu/conference

9-15 September, 2012: ISESCO/WREN International Seminar in Britain; Theme: Renewable Energy- Policy, Security, Electricity, Sustainable Transport, Water Resources/ Management and the Environment. Location: Brighton, East Sussex, UK. More info: http://www. wrenuk.co.uk

9-12 September, 2012: Energy Challenge and Environmental Sustainability. Location: Venice, Italy. More info: www.iaeeu2012.it

10-12 September, 2012: International Conference on Clean Energy. Location: Quebec, Canada. More info: http://iaemm.com/ICCE_Home/

17-18 September, 2012: Energy from Waste. Location: London, UK. More info: www.smionline.co.uk/2012energy-waste31.asp

18-19 September, 2012: FT Global Energy Leaders Summit 2012. Location: London, UK. More info: www.ft-live.com/energy

24-27 September, 2012: 3rd International Conference on Sustainable energy Technology (ICSET'2). Kathmandu, Nepal. Contact mail: www. ieee-icst.org/index /

2-4 October, 2012: Renewable Energy World Conference and Expo Asia sponsored by PennWell Corporation. Location: Bangkok, Thailand. Contact
Email: amyn@pennwell.com. More info: www. renewableenergyworld-asia.com

3-5 October, 2012: POWER-GEN Asia. Location: Bangkok, Thailand. More info: www.powergenasia. com

3-5 October, 2012: Renewable Energy World Asia. Location: Bangkok, Thailand. More info: www. renewableenergyworld-asia.com

10-12 October, 2012: 1st International Off-grid Renewable Energy Conference. Location: Accra, Ghana. More info: http://www.ruralelec.org

12-14 October, 2012: International Seminar and Workshop on Energy, Sustainability and Development. Location: Assam, India. More info: http://sibsagarcollege.in/iswesd2012.html

22-23 October, 2012: International Conference on Solar Energy for MENA region-INCOSOL 2012. Location: Amman, Jordan. More info: http:// www.incosol2012.ressol-medbuild.eu

22-24 October, 2012: World Energy Forum. Location: Dubai, United Arab Emirates. More info: http://worldenergyforum2012.org/

29-31 October, 2012: Global Energy 2012. Location: Geneva, Switzerland. More info: http://www. globalenergygeneva.com

30 October - 1 November, 2012: Renewable UK 2012. Location: Glasgow, Scotland, UK. More info: http://www.renewable-uk.com/events/annualconference

Continued in page 66 